\title{
2: 74971437-75032136
}

National Cancer Institute

\section{Source}

National Cancer Institute. 2: 74971437-75032136. NCI Thesaurus. Code C42465.

Physical location of HK2_Gene 